\title{
Investigation of the Clinical Course and Outcomes of Bonsai Use
}

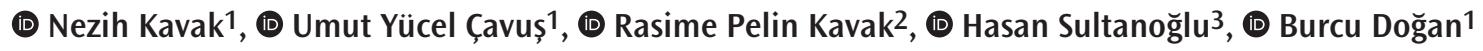 \\ ${ }^{1}$ Clinic of Emergency Medicine, University of Health Sciences, Ankara Dıșkapı Yıldııım Beyazıt Training and Research Hospital, Ankara, Turkey \\ ${ }^{2}$ Clinic of Radiology, University of Health Sciences, Ankara Dıșkapı Yıldırım Beyazıt Training and Research Hospital, Ankara, Turkey \\ ${ }^{3}$ Clinic of Emergency Medicine, Dr. Ersin Arslan Training and Research Hospital, Gaziantep, Turkey
}

\begin{abstract}
Aim: We aimed to contribute to the contemporary literature by investigating the clinical course and outcomes of bonsai, a synthetic cannabinoid with progressively increasing use.

Materials and Methods: Our study retrospectively reviewed the medical records of 149 patients with symptoms related to bonsai use. The parameters included age, gender, blood pressure, heart rate, respiratory rate, body temperature, Glasgow coma scale, route and duration of bonsai use, time used, symptoms, follow-up period in the emergency department, regular ward and intensive care unit, need for mechanical ventilation, biochemistry panel, abstinence, intoxication, mortality, and morbidity.

Results: The most common symptoms were agitation (49.7\%) and anxiety (28.9\%). Intoxication was correlated with creatinine and creatine kinase-myocardial band $(p<0.05)$. Patients who were intoxicated had more agitation, impaired consciousness, and speech disturbances $(p<0.05)$. The mean emergency department follow-up period was 8 hours. The follow-up period was 4 days in the intensive care unit and 2 days in the regular ward. The overall mortality rate was $2 \%$.
\end{abstract}

Conclusion: Bonsai use is characterized by ischemic symptoms and can therefore be fatal.

Keywords: Bonsai, synthetic cannabinoids, emergency department

\section{Introduction}

Narcotic substance use and addiction is a major public health problem worldwide. Novel or atypical narcotic substances have been developed in the last decade. Among these, cheaper and easily accessible ones have become increasingly popular (1).

Tetrahydrocannabinol is a synthetic cannabinoid and its derivatives were first manufactured in Europe in 2004 under the name Bonsai (2). Having the central effects of marijuana, these substances have been introduced as "harmless", "legal marijuana", and as "a designed drug" (2). Being readily accessible and cheap, as well as lacking the narcotic substance status, these substances have gained a rapidly increasing popularity, particularly among adolescents and young adults $(3,4)$.
Today, synthetic cannabinoids have 11 groups, containing 130 subgroups (5). Although synthetic cannabinoids exert sympathetic effects such as palpitation, sweating, agitation and restlessness, the diversity of synthetic cannabinoid combinations and manufacturing techniques complicate clinical predictions about their effects $(6,7)$. Recently, it has been reported that they cause severe conditions such as myocardial infarction, pulmonary embolism, ischemic stroke, seizure, acute renal failure and death (8-10). Cases of intoxication have also been reported recently due their widespread use (11).

In this study, we aimed to contribute to the contemporary literature by investigating the clinical course and outcomes of Bonsai use, a synthetic cannabinoid with increasing popularity.

Corresponding Author: Nezih Kavak, Clinic of Emergency Medicine, University of Health Sciences, Ankara Dıșkapı Yıldırım Beyazıt Training and Research Hospital, Ankara, Turkey Phone: +90 5322551179 E-mail: nezih_kavak@hotmail.com ORCID ID: orcid.org/0000-0003-2751-0046

Cite this article as: Kavak N, Çavuș UY, Kavak RP, Sultanoğlu H, Doğan B. Investigation of the Clinical Course and Outcomes of Bonsai Use. Eurasian J Emerg Med. 2019;18(2):72-8.

(C) Copyright 2019 by the Emergency Medicine Physicians' Association of Turkey Eurasian Journal of Emergency Medicine published by Galenos Publishing House. 


\section{Materials and Methods}

Our study was retrospectively performed on patients who presented to the emergency department of our hospital with complaints related to isolated Bonsai use between January 1 , 2013 and December 31, 2015 in Ankara, Turkey.

\section{Study Population and Data Collection}

The medical records of patiens were accessed via hospital automation system and patient follow-up cards. Patient data were recorded in specific forms prepared for each patient and were then transferred to a computer.

A total of 170 patients, who presented to our hospital's emergency department with disturbing symptoms after Bonzai intake, were enrolled. JWH-18 and JWH-73 metabolites in urine samples were searched using the Rapid K2 Test Card [An immunochromatographic assay for the rapid visual detection of synthetic cannabis (K2) in human urine]. Twenty-one patients with no noticeable metabolite were excluded. Among patients with noticeable urinary metabolites, other narcotic drugs were screened in urine using a toxicology panel. Ethanol level was measured from blood samples obtained from all patients. We excluded patients with following conditions: under the age of 18 , history of using any additional substance, lacking complete medical data, receiving medical treatment for any other disorder and limited access to medical records. The recorded data included age, gender, vital parameters [systolic blood pressure (SBP), diastolic blood pressure (DBP), pulse rate, respiratory rate, and saturation], Glasgow coma scale (GCS), route and duration of Bonsai use, time used, symptoms, follow-up period (emergency department, regular ward, and intensive care unit), need for mechanical ventilation, biochemical parameters (glucose, urea, creatinine, potassium, aspartate transaminase (AST), alanine aminotransferase (ALT), creatine kinase (CK), and creatine kinasemyocardial band (CK-MB), abstinence, intoxication (Table 1), and mortality.

Table 1. Diagnostic criteria for cannabis-induced intoxication

\begin{tabular}{ll}
\hline A. & Recent cannabis use \\
\hline B. & $\begin{array}{l}\text { Clinically significant behavioral or psychological alterations } \\
\text { that occur during or shortly after cannabis use }\end{array}$ \\
\hline C. & $\begin{array}{l}\text { The occurrence of two or more of the criteria below within } \\
2 \text { hours of cannabis use (conjunctival redness, increased } \\
\text { appetite, dry mouth, tachycardia) }\end{array}$ \\
\hline D. $\quad \begin{array}{l}\text { Admission signs and symptoms either incompatible with } \\
\text { ony any other substance or any other mental disorder }\end{array}$ \\
\hline
\end{tabular}

\section{Statistical Analysis}

The study data were analyzed using the Statistical Package for Social Sciences 18.0 for Windows package program (SPSS Inc., Chicago, IL, USA). Kolmogorov-Smirnov test was used to test the normality of the distribution of continuous and discrete numerical variables. Descriptive statistics included median, interquartile range (IQR), and minimum-maximum values for nonparametric continuous and discrete numerical variables, and number and percentage (\%) for categorical variables. The nonparametric variables were analyzed using Mann-Whitney $U$ test and the categorical variables using chi-square and Fisher's exact chi-square test. Unless stated otherwise, a p-value less than 0.05 was considered statistically significant for all comparisons.

\section{Results}

This study included a total of 149 patients (121 male and 28 female) with a median age of 25 years [IQR: 6.5]. According to the follow-up data and treatment results, 123 (82.5\%) patients had symptoms related to Bonsai use and $26(17.5 \%)$ to Bonsai Abstinence syndrome. The development of Bonsai intoxication was not correlated with age and gender (Table 2). The most common route of Bonsai use was smoking, and the majority of patients had a history of repetitive Bonsai use. No significant correlation was found between the route and duration of Bonsai use and intoxication $(\boldsymbol{p}<0.05)$ (Table 2$)$.

Intoxication was not correlated with SBP, DBP, pulse rate, respiratory rate, body temperature, saturation, and GCS ( $p>0.05)$ (Table 2). It was also not correlated with glucose, AST, ALT, BUN, potassium, and CK levels ( $p>0.05)$, whereas creatinine and CKMB levels were significantly increased in patients who were intoxicated $(p<0.05)$ (Table 3).

Patients admitted to the intensive care unit had higher heart rate, respiratory rate, glucose, AST, ALT, urea, creatinine, and CKMB levels, but a lower GCS $(p<0.05)$. The patients who died had higher heart rate, respiratory rate, and glucose levels, but GCS was lower $(\boldsymbol{p}<0.05)$ (Table 3).

Ninety-two percent of patients were discharged from the emergency department, $7.4 \%$ were admitted to the intensive care unit and $0.6 \%$ were admitted to a regular ward (Table 3). Six (4.0\%) patients needed mechanical ventilation. The followup period was eight hours [IQR: 4] in ED, four days [IQR: 3] in intensive care unit and two days in regular ward. The intoxicated patients had significantly longer ED follow-up periods $(p<0.05)$ (Table 3). The overall mortality rate was $2 \%$ (Table 3 ). All patients who were admitted, who needed mechanical ventilation and who died were intoxicated (Table 4). 


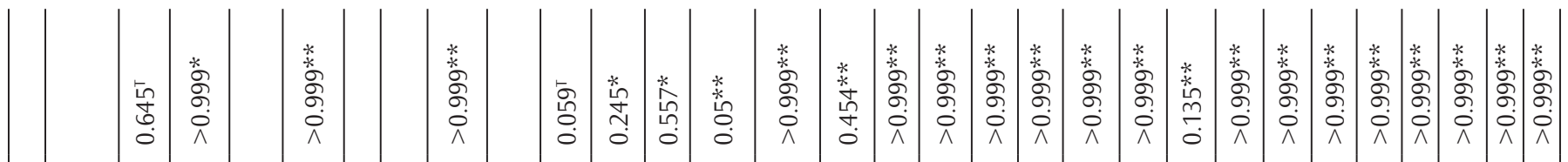

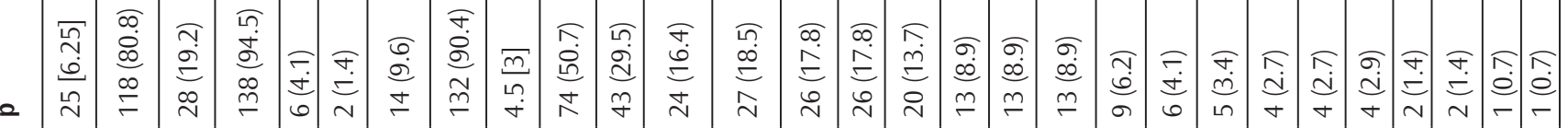

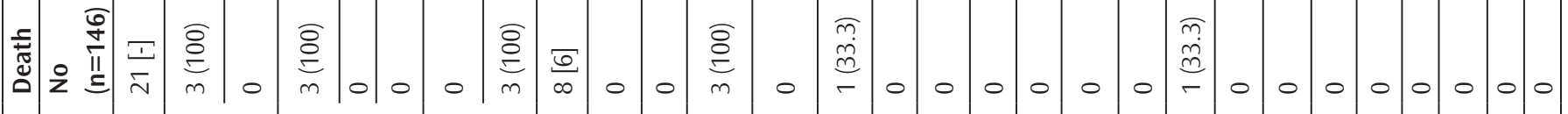

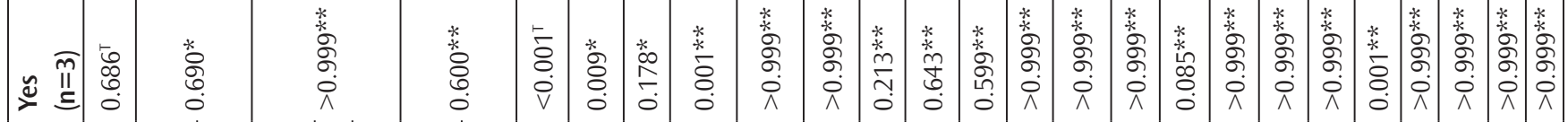

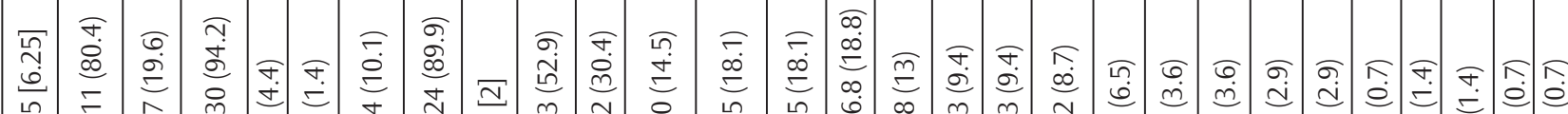
离

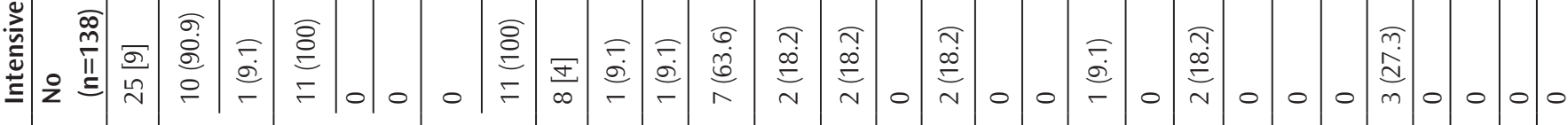

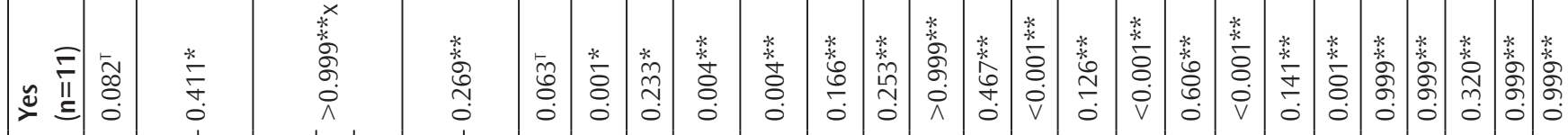

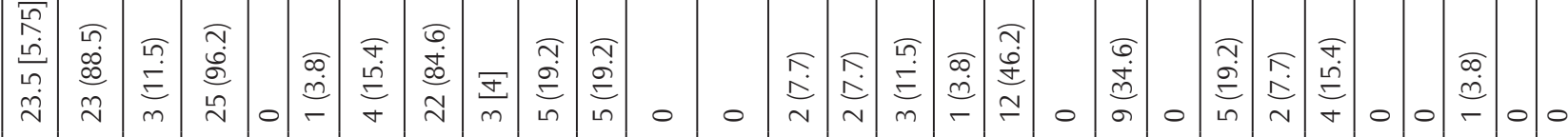

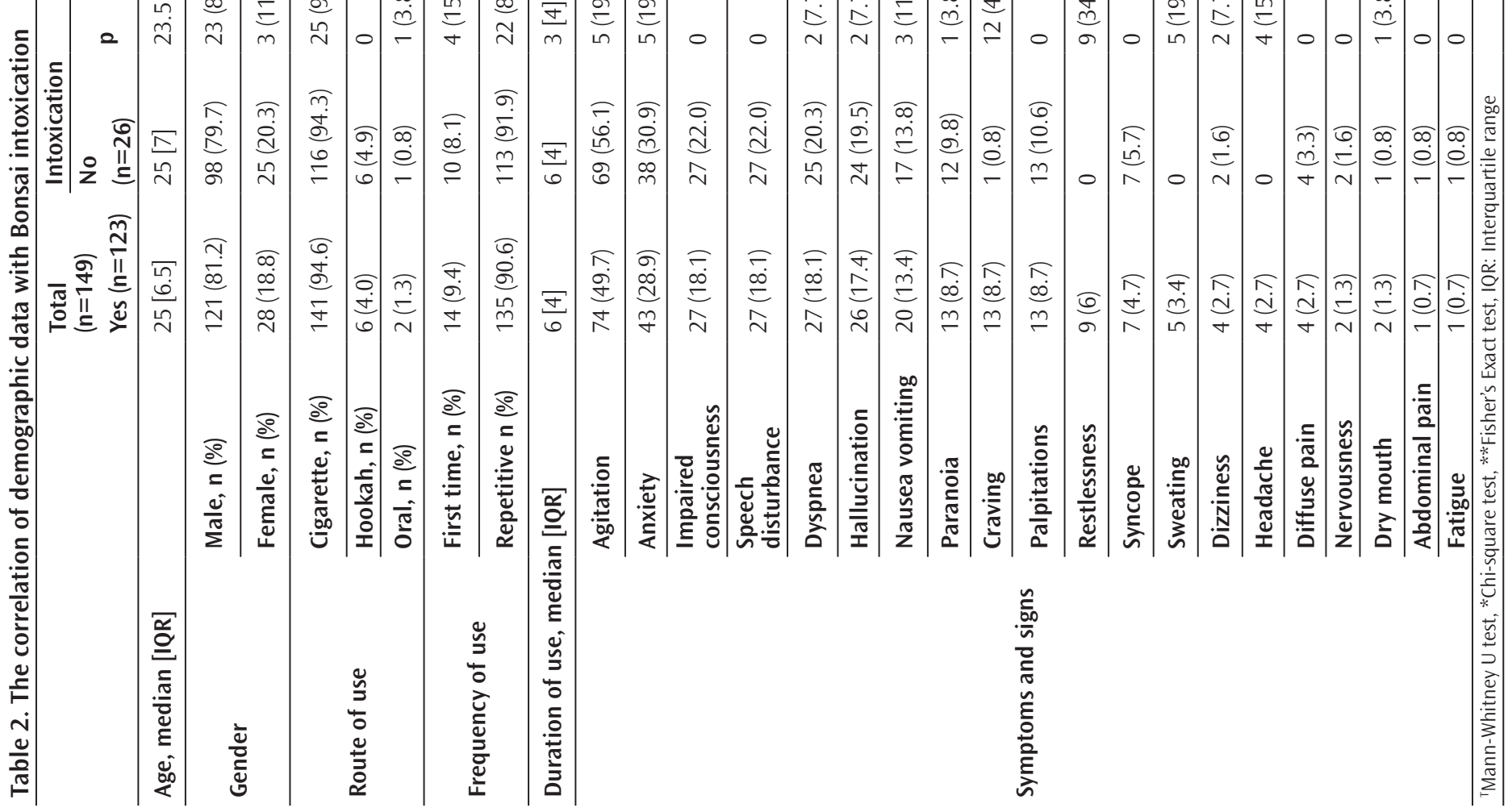




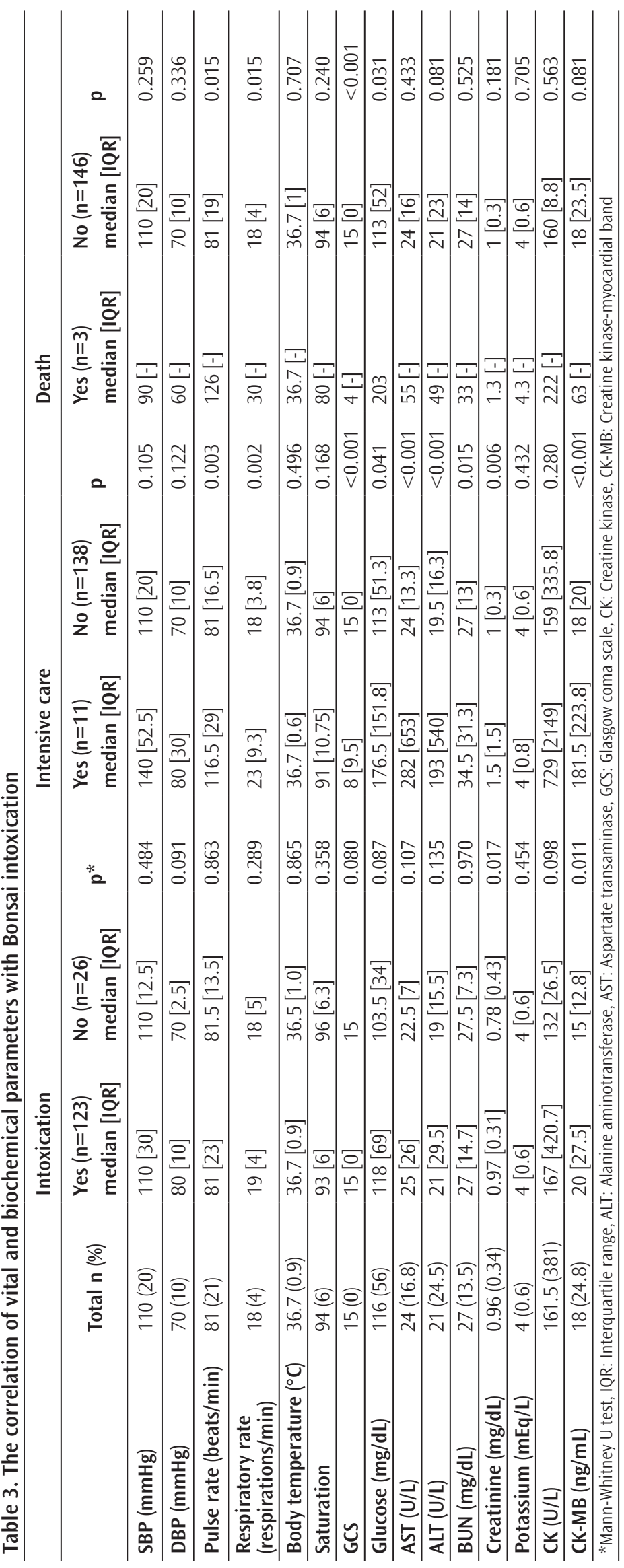

Table 4. The correlations of admission status, need for mechanical ventilation, and follow-up durations with intoxication

\begin{tabular}{|c|c|c|c|c|}
\hline & \multirow[t]{2}{*}{$\begin{array}{l}\text { Total } \\
(n=149)\end{array}$} & \multicolumn{3}{|c|}{ Intoxication } \\
\hline & & $\begin{array}{l}\text { Yes } \\
(n=123)\end{array}$ & $\begin{array}{l}\text { No } \\
(n=26)\end{array}$ & p \\
\hline Discharged from ED & 137 (92) & $111(90.2)$ & $26(100)$ & \multirow{3}{*}{0.127} \\
\hline $\begin{array}{l}\text { Intensive care unit } \\
\text { admission }\end{array}$ & $11(7.4)$ & $11(9.0)$ & 0 & \\
\hline $\begin{array}{l}\text { Regular ward } \\
\text { admission }\end{array}$ & $1(0.6)$ & $1(0.8)$ & 0 & \\
\hline $\begin{array}{l}\text { Need for } \\
\text { mechanical } \\
\text { ventilation, } n(\%)\end{array}$ & $6(4.0)$ & $6(4.0)$ & 0 & 0.591 \\
\hline $\begin{array}{l}\text { Follow-up period in } \\
\text { the ED (hours) }\end{array}$ & $8(4)$ & $6(4)$ & $2.5(1.3)$ & $<0.001$ \\
\hline $\begin{array}{l}\text { Follow-up period in } \\
\text { the intensive care } \\
\text { unit }\end{array}$ & $4(3)$ & $4(3)$ & - & $\mathrm{N} / \mathrm{A}$ \\
\hline $\begin{array}{l}\text { Follow-up period } \\
\text { in the regular ward } \\
\text { (days) }\end{array}$ & 2 & 2 & - & $\mathrm{N} / \mathrm{A}$ \\
\hline Mortality n (\%) & $3(2.0)$ & $3(2.4)$ & 0 & 0.421 \\
\hline ED: Emergency departme & & & & \\
\hline
\end{tabular}

Although synthetic cannabinoids were originally produced as therapeutic agents, they were sold as marijuana alternatives stuffed in dried plants after being synthesized in laboratories in the early 2000s (12). Although their use is increasingly common, their toxic effects and medical consequences are not fully known $(11,13,14)$.

It is known that all forms of narcotic substance use are common among young males $(7,15-17)$. The median age of our patients was 25 years and $81.2 \%$ of them were male. No correlation was found between intoxication and gender or age. We believe that Bonsai use is common among young males, because they frequently spend their time in places where Bonsai use is common, and they perceive drug use as a means to draw attention or a sign of courage. Compared to other substances, being cheap and more easily accessible may also have made Bonsai more popular among young people. We believe that bonsai users are predominantly young, because more potent substances (heroin, cocaine, etc.) are used later in life. A greater mortality rate is associated with their use and users undergo rehabilitation. We opine that intoxication with these substances 
is more linked to their properties, amount, and duration of exposure than the age or gender of the patient.

Published reports suggest that although synthetic cannabinoids are generally used in cigarette form, they can be inhaled in vaporized form or taken orally or rectally $(2,3,18)$. In our study, cigarette form was the most common form (94.6\%), but the route of use was not significantly correlated to intoxication. Although Bonsai is best suited for inhaled use in cigarette form, we think that some patients may try other forms to cause a change or to get more pleasure. Since both the number of people who tried other forms and the amount of substance used by these routes were small, it did not make a significant difference with regard to intoxication.

Doğan et al. (3) reported that $74.2 \%$ of patients, who had a higher rate of liver and renal dysfunction, had a history of substance use, although the difference did not reach statistical significance (2). On the other hand, $90.6 \%$ of our patients had been using Bonsai for six months. Intoxication was independent of the duration of repetitive substance use. We believe that the repetitive Bonsai use has gradually increased due to addiction potential and abstinence symptoms. However, the duration of Bonsai use is shorter in Turkey due to its recent introduction to this country, and signs of intoxication more commonly appear in case of hepatic and renal dysfunction caused by worsening hypoxia in the long term.

Synthetic cannabinoids are partial or complete agonists of CB1 receptors. They cause adverse effects such as sweating, nausea, vomiting, appetite disorders, hyper/hypotension, chest pain, tachycardia/bradycardia, respiratory depression, confusion, psychomotor agitation, somnolence, and sedation in addition to their usual effects including euphoria, anxiety, agitation, irritability, psychosis, and altered cognitive skills $(2,7,19,20)$. Barratt et al. (16) reported that $68 \%$ of patients experienced at least one side effect, the most common of which was impaired motor coordination (39\%). Doğan et al. (3) stated that dizziness and agitation were the most common symptoms. Zimmermann et al. (21) stressed that patients regularly using Bonsai may suffer from signs and symptoms of abstinence syndrome, which include shivering, headache, nightmares, craving, hypertension, and tachycardia. Forrester reported that $48.5 \%$ of the patients presented with palpitations and chest pain, and 24.3\% with dizziness and vertigo (22). We demonstrated that the most common symptoms among intoxicated patients were agitation, speech disturbance, and altered consciousness. Many symptoms have been linked to Bonsai use in the literature. This may be a result of different CB-1 receptor affinities, potencies, doses, and duration of the effect of different synthetic cannabinoid subgroups. Considering that the patient group with signs of abstinence syndrome also had a high anxiety rate, we think that the symptoms of Bonsai use are largely similar.

At low to moderate doses, cannabinoids induce tachycardia and increase cardiac output by a sympathomimetic effect whereas, at higher doses, they cause bradycardia and hypotension by their parasympathomimetic effect $(23,24)$. Studies conducted so far have shown that affected patients most commonly experienced tachycardia and hypertension, while bradycardia and hypotension were less common (25-28). We could not find any abnormal vital parameters except for tachypnea, and vital parameters were not correlated to intoxication status. We believe that our patients generally used low to moderate doses of Bonsai, and its effects started to wane over time. We think that tachypnea occurred as a result of anxiety in both groups. Anxiety caused similar vital parameters in patients with abstinence symptoms and intoxicated patients.

Former studies have shown glucose, urea, creatinine and CK elevation and hypopotassemia with Bonsai use (29-31). Doğan et al. (3) reported higher CK, CK-MB, AST, ALT and creatinine levels in Bonsai users. In a series of 6 patients, Ergül et al. (32) demonstrated that BUN, creatinine, CK, LDH, AST and ALT levels were elevated. The authors attributed this result to the possibility of a variety of substances being admixed with synthetic cannabinoids, such as agricultural chemicals, fluorescent dust, Veronika and industrial chemicals (32). Altınışık et al. (27) reported that four of 12 patients admitted to intensive care unit after using Bonsai had impaired hepatic and renal function, with renal function recovered in 48 hours but hepatic markers remained elevated for a longer period. It was reported that synthetic cannabinoid use was associated with acute tubular necrosis, resulting in acute renal failure $(30,31,33)$. Sheikh et al. (34) reported hepatocellular necrosis and hepatic failure in a patient using Bonsai.

Our study demonstrated that creatinine and CK-MB were higher in intoxications, that patients admitted to the intensive care unit had a higher heart rate, respiratory rate, glucose, AST, ALT, urea, creatinine, and CK-MB levels, but a lower GCS and that the deceased patients had higher heart rate, respiratory rate, and glucose level, but a lower GCS. We believe that organ injuries develope due to ischemia affecting all tissues, so blood levels increase and GCS falls. The release of stress hormones in response to increased stress levels may explain elevated glucose levels.

The majority of synthetic cannabinoids have an effect period of 2-6 hours, although some may have persistent effects beyond 24 hours $(13,17,29,35)$. Some studies reported that consciousness was regained within 8-12 hours after the Bonsai use unless there were additional complications $(29,35)$. It has been reported that a variety of fatty acids, herbal compounds, preservatives like 
benzyl benzoate, and addictive substances like alpha-tocopherol, which are used for synthetic cannabinoid manufacturing or are naturally found in the plant's chemical structure, may extend the duration of action of B2 adrenergic agonists up to 24 hours (36).

In our study, the duration of ED follow-up was eight hours, with the duration for intoxicated patients being significantly longer. Our results are in accordance with the previous literature, and we believe that patients whose symptoms improved were either discharged or admitted for a period of approximately eight hours. We believe that relief of the abstinence symptoms by therapy resulted in a rapid discharge of patients who were free of intoxication.

While synthetic cannabinoids have not been consistently reported to cause respiratory difficulty and/or respiratory arrest (37), pulmonary fluid accumulation and respiratory depression due to long-term synthetic cannabinoid use have been reported $(36,38)$. Altınışık et al. (27) reported that one of 12 patients with loss of consciousness due to Bonsai use needed intubation. Küçük et al. (7) reported that 3\% required intubation. Four percent of our patients were intubated. Although all intubated patients were intoxicated, this tendency was not statistically significant. We believe that patients developed respiratory arrest due to increased fluid accumulation in lungs and/or due to other narcotic substances used in combination with Bonsai.

Monte et al. (39) reported that 9\% of patients were hospitalized. A domestic study by Küçük et al. (7) showed that $46 \%$ of patients were hospitalized, of whom half were monitored in the the intensive care unit Lank et al. (40) reported that the level of knowledge among ED physicians about synthetic cannabinoids was low, which resulted in a high admission rate. Our study demonstrated that $7.4 \%$ of patients were admitted to the intensive care unit and $0.6 \%$ to a regular ward and that all admitted patients were intoxicated at admission. We believe that patients who were not intoxicated and the majority of intoxicated patients had a relatively stable overall status and were therefore treated in the ED from where they were discharged. The reason for the high rate of intensive care admission may be the impending risk of respiratory arrest during admission.

Among patients who were admitted to the intensive care unit for intoxication, the intensive care follow-up period was reported to be three days $(41,42)$. Altınışık et al. (27) reported that most of the patients admitted to the intensive care unit after synthetic cannabinoid use regained consciousness by 24 hours and the remainders by 48 hours. They reported a follow-up period of three days and recommended a follow-up period of at least three days (27). In our study, the intensive care follow-up period was four days, and the regular ward follow-up period was two days.
As synthetic cannabinoid types are variable and their duration of effect is largely unknown, we believe that intensive care unit follow-up should be sufficiently long.

No death occurred among nine patients of Buser et al. (30) and 12 patients of Altınışık et al. (27). According to Turkey Drug Report published in 2013, seven drug-related deaths occurred due to synthetic cannabinoids and three deaths occurred due to the combined use of marijuana and synthetic cannabinoids in the second half of 2012 (43). The overall mortality rate in our study was $2 \%$. Although all deceased patients were also intoxicated, this trend did not reach statistical significance. Deaths may have developed as a result of irreversible injury caused by worsening hypoxia. The major factor giving rise to our higher mortality rate may be the referral of patients with poor overall status to our center from neighboring district hospitals.

\section{Study Limitations}

Since the present study had a retrospective design, we could not obtain any information about patient anamnesis, history, family history, and details of additional substance use (Was the patient addicted to any other substance? Which substance, other than Bonzai, was recently taken and when?). Similarly, complete blood count, blood gas analysis, and other biochemical parameters could not be analyzed.

\section{Conclusion}

Particularly affecting young people, Bonsai use is characterized by ischemic symptoms and can therefore be fatal. Strict measures should be taken in emergency departments and more robust security policies should be implemented to reduce mortality and morbidity associated with Bonsai use. It is also necessary to prohibit the production and use of Bonsai.

\section{Ethics}

Ethics Committee Approval: University of Health Sciences Dışkapı Yıldırım Beyazıt Training and Research Hospital, Ankara, Turkey, approval number: 32/06 22.11.2016.

Informed Consent: Retrospective study.

Peer-review: Externally peer-reviewed.

\section{Authorship Contributions}

Surgical and Medical Practices: N.K., Concept: N.K., U.Y.C.., Design: N.K., U.Y.Ç., Data Collection or Processing: N.K., H.S., B.D., Analysis or Interpretation: N.K., R.P.K., Literature Search: N.K., U.Y.C.., R.P.K., H.S., B.D., Writing: N.K.

Conflict of Interest: No conflict of interest was declared by the authors 
Financial Disclosure: The authors declared that this study received no financial support.

\section{References}

1. Orsini J, Blaak C, Tam E, Rajayer S, Morante J, Yeh A, et al. The wide and unpredictable scope of synthetic cannabinoids toxicity. Case Rep Crit Care. 2015;2015:542490.

2. Artuç S, Doğan KH, Demirci Ş. Uyușturucu maddelerde yeni trend: sentetik kannabinoidler. Adli Tıp Bülteni. 2014;19:198-203.

3. Doğan H, Özüçelik DN, Açıksarı K, Avcı A, Yazııı̆lu M, Çelikmen MF, et al. New synthetic cannabinoid intoxications in emergency department (It's grass, it's no sin). Anadolu Psikiyatri Derg. 2016;17:18-25.

4. Aoun EG, Christopher PP, Ingraham JW. Emerging drugs of use: clinical and legal considerations. RI Med J (2013). 2014;97:41-5.

5. Office of National Drug Control Policy. (2014). Fact sheet: Synthetic drugs (a.k.a. K2, Spice, bath salts, etc.). http://www.whitehouse.gov/ondcp/ondcpfact-sheets/synthetic-drugs-k2-spice-bath-salts Son erişim tarihi:01.01.2017.

6. Hudson S, Ramsey J, King L, Timbers S, Maynard S, Dargan PI, et al. Use of high-resolution accurate mass spectrometry to detect reported and previously unreported cannabinomimetics in "herbal high" products. J Anal Toxicol. 2010;34:252-60.

7. Küçük E, Küçük I, Kirazaldı YY. Acil serviste yeni bir tehlike: Sentetik kannabinoidler (Bonsai, Jameika). Genel Tıp Derg. 2015;25:18-22.

8. Freeman MJ, Rose DZ, Myers MA, Gooch CL, Bozeman AC, Burgin WS. Ischemic stroke after use of the synthetic marijuana "spice". Neurology. 2013;81:2090-3.

9. Thornton SL, Wood C, Friesen MW, Gerona RR. Synthetic cannabinoid use associated with acute kidney injury. Clin Toxicol (Phila). 2013;51:189-90.

10. McKeever RG, Vearrier D, Jacobs D, LaSala G, Okaneku J, Greenberg MI. K2-not the spice of life; synthetic cannabinoids and ST elevation myocardial infarction: a case report. J Med Toxicol. 2015;11:129-31.

11. Eminler AT, Yıldırım M, Uslan Mi, Köksal AŞ, Parlak E. Sentetik kannabinoidler (BONZAi) ve gastrointestinal sistem üzerine etkileri: "Kannabinoid Hiperemezis Sendromu”. Güncel Gastroentereloji. 2014;18:460-3.

12. Atik SU, Dedeoğlu R, Varol F, Çam H, Eroğlu AG, Saltık L. Cardiovascular side effects related with use of synthetic cannabinoids "bonzai": two case reports. Turk Pediatri Ars. 2015;50:61-4.

13. EMCDDA 2013 Ulusal Raporu (2012 Verileri) Reitox Ulusal Temas Noktası. Türkiye Uyușturucu Ve Uyușturucu Bağımlılığı İzleme Merkezi (TUBiM) Ankara 2013.

14. Bozkurt M, Umut G, Evren C, Karabulut V. Sentetik kannabinoid kullanımı nedeniyle polikliniğe başvuran hastaların klinik özellikleri ve laboratuvar sonuçları. Düşünen Adam Psikiyatri ve Nörolojik Bilimler Dergisi. 2014;27:328-34.

15. Hu X, Primack BA, Barnett TE, Cook RL. College students and use of K2: an emerging drug of use in young persons. SubstAbuse Treat Prev Policy. 2011;6:16.

16. Barratt MJ, Cakic V, Lenton S. Patterns of synthetic cannabinoid use in Australia. Drug Alcohol Rev. 2013;32:141-6.

17. Hoyte CO, Jacob J, Monte AA, Al-Jumaan M, Bronstein AC, Heard KJ. A characterization of synthetic cannabinoid exposures reported to the National Poison Data System in 2010. Ann Emerg Med. 2012;60:435-8.

18. Vandrey R, Dunn KE, Fry JA, Girling ER. A survey study to characterize use of Spice products (synthetic cannabinoids). Drug Alcohol Depend. 2012;120:238-41.

19. Schneir AB, Cullen J, Ly BT. "Spice" girls: synthetic cannabinoid intoxication. J Emerg Med. 2011;40:296-9.

20. Castellanos D, Singh S, Thornton G, Avila M, Moreno A. Synthetic cannabinoid use: a case series of adolescents. J Adolesc Health. 2011;49:347-9.
21. Zimmermann US, Winkelmann PR, Pilhatsch M, Nees JA, Spanagel R, Schulz K Withdrawal phenomena and dependence syndrome after the consumption of "spice gold". Dtsch Arztebl Int. 2009;106:464-7.

22. Forrester MB. Adolescent synthetic cannabinoid exposures reported to Texas poison centers. Pediatr Emerg Care. 2012;28:985-9.

23. Sarımehmetoğlu AC, Helvacı A. Madde Bağımlılığı ve Kardiyovasküler Sistem. Eur Arch Med Res. 2014;30:99-103.

24. Bashour TT. Acute myocardial infarction resulting from amphetamine abuse: a spasm-thrombus interplay? Am J Heart J. 1994;128:1237-9.

25. Ekim M, Ekim H. Sentetik Kannabinoidlerin (Bonzai) Kullanılmasına Bağlı Psișik ve Kardiyovasküler Rahatsızıklar. Tıp Araștırmaları Dergisi. 2016;14:79-83.

26. Bachs L, Mørland H. Acute cardiovascular fatalities following cannabis use. Forensic Sci Int. 2001;124:200-3.

27. Altınışık U, Altınıșık HB, Șimșek T, Doğu T, șimşek E, Aydın H. Clinical Characteristics of Patients Diagnosed with Synthetic Cannabinoid (Bonsai) Intoxication in ICU. J Turk Soc Intens Care. 2015;13:117-21.

28. Parlakpinar H, Celbis O, Onural Ö, Petekkaya S, Şamdancı E, Ermiş N, et al. Cardiovascular effects of JWH-018 from synthetic cannabinoids. Medicine Science. 2016;5:1049-54.

29. Hermanns-Clausen M, Kneisel S, Szabo B, Auwärter V. Acute toxicity due to the confirmed consumption of synthetic cannabinoids: clinical and laboratory findings . Addiction. 2013;108:534-44.

30. Buser GL, Gerona RR, Horowitz BZ, Vian KP, Troxell ML, Hendrickson RG, et al. Acute kidney injury associated with smoking synthetic cannabinoid. Clin Toxicol (Phila). 2014;52:664-73.

31. Taskiran B, Mutluay R. A Case of Hypokalemia with Synthetic Cannabinoid Use. Medicine Science. 2014;3:1713-8.

32. Ergül DF, Ekemen S, Yelken BB. Synthetic Cannabinoid 'Bonsai'Intoxication: Six Case Series. Turk J Anaesthesiol Reanim. 2015;43:347.

33. Gudsoorkar VS, Perez JA Jr. A new differential diagnosis: synthetic cannabinoids-associated acute renal failure. Methodist Debakey Cardiovasc J. 2015;11:189-91.

34. Sheikh IA, Lukšic M, Ferstenberg R, Culpepper-Morgan JA. Spice/K2 synthetic marijuana-induced toxic hepatitis treated with $\mathrm{N}$-acetylcysteine. Am J Case Rep. 2014;15:584-8.

35. Simmons JR, Skinner CG, Williams J, Kang CS, Schwartz MD, Wills BK. Intoxication from smoking "spice". Ann Emerg Med. 2011;57:187-8.

36. Evren C, Bozkurt M. Synthetic cannabinoids: Crisis of the decade. Düşünen Adam: The Journal of Psychiatry and Neurological Sciences. 2013;26:1-11.

37. Kalyoncu ÖA, Ünlü B, Taștan U. A Dangerous Game That May Harm Kids and Teens: A Review on Synthetic Cannabinoids (Bonzai). Dergisi-Journal of Dependence. 2014;15:150-5.

38. Hopkins CY, Gilchrist BL. A case of cannabinoid hyperemesis syndrome caused by synthetic cannabinoids. J Emerg Med. 2013;45:544-6.

39. Monte AA, Bronstein AC, Cao DJ, Heard KJ, Hoppe JA, Hoyte CO, et al. An outbreak of exposure to a novel synthetic cannabinoid. N Engl J Med. 2014:370:389-90.

40. Lank PM, Pines E, Mycyk MB. Emergency physicians' knowledge of cannabinoid designer drugs. West J Emerg Med. 2013;14:467-70.

41. Özayar E, Değerli S, Güleç H, Sahin S, Dereli N. Retrospective analysis of intoxication cases in the ICU. J Turk Soc Intens Care. 2011;3:59-62.

42. Yağan Ö, Akan B, Erdem D, Albayrak D, Bilal B, Gögüus N. The retrospective analysis of the acute poisoning cases applying to the emergency unit in one year. The Medical Bulletin of Sisli Etfal Hospital. 2009;43:60-4.

43. 2013 Türkiye Uyușturucu Raporu. http://www.kom.gov.tr/Tr/Dosyalar/2013 _turkıye_uyusturucu_raporu.pdf. Son erişim Tarihi:07/01/2017. 